\title{
Dose of colistin: a work in progress?
}

\author{
Monica Rocco ${ }^{*}$, Luca Montini, Gennaro De Pascale and Massimo Antonelli \\ See related letters by Rashid et al., http://ccforum.com/content/18/1/401, and Honoré et al., http://ccforum.com/content/18/1/412, and related research \\ by Rocco et al. http://ccforum.com/content/17/4/R174
}

We thank Rashid and colleagues [1] and Honoré and colleagues [2] for their comments regarding our article on risk factors for acute kidney injury in patients receiving colistin or other nephrotoxic antimicrobials [3].

It is correct that we did not specifically report urine output in the text, but it was obviously included in the RIFLE (Risk, Injury, Failure, Loss of kidney function, and End-stage kidney disease) criteria reported in Table two [3].

We agree that the colistin methanesulfonate pharmacokinetics have been better studied recently, and it has become clear that high doses are required for treating multidrug-resistant Gram-negative bacilli infection, including the loading dose (which has changed from 4 to 9 million IU) and the dose interval (which has changed from three to two times a day) [4]. We agree with the authors' concerns about the adequacy of colistin dosages adopted in our cohort $(130,000 \mathrm{IU} / \mathrm{kg}$ of ideal body weight, modified according to renal function), but these doses were commonly adopted, especially in patients with renal impairment [5]. Indeed, the development of new high-performance liquid chromatography assays that allow clinicians to measure the concentrations of colistimethate and colistin separately has shown that colistin clearance is due mainly to non-renal mechanisms that are still unclear. It is of great interest to note, as reported recently by Honoré and colleagues [6], that patients with multidrug-resistant infections can receive even higher doses of colistin during continuous renal replacement therapy, as colistin methanesulfonate is continuously filtered and absorbed by dialysis membrane [7]. Hence, even higher doses may be needed in patients receiving continuous renal replacement therapy than in patients with normal renal function. The growing evidence in favor of a higher dosage of colistin requires further clinical studies.

\section{Competing interests}

The authors declare that they have no competing interests.

Published online: 16 February 2015

\section{References}

1. Rashid S, Saro-Nunez L, Kumar A, Patel A, Parikh A. Acute kidney injury: taking aim at colistin. Crit Care. 2014;18:401.

2. Honoré PM, Jacobs R, De Regt J, Van Gorp V, De Waele E, Spapen HD. Colistin dosing for treatment of multidrug-resistant Pseudomonas in critically ill patients - please, be adequate! Crit Care. 2014;18:412.

3. Rocco M, Montini L, Alessandri E, Venditti M, Laderchi A, De Pascale G, et al. Risk factors for acute kidney injury in critically ill patients receiving high intravenous doses of colistin methanesulfonate and/or other nephrotoxic antibiotics: a retrospective cohort study. Crit Care. 2013;17:R174.

4. Mohamed AF, Karaiskos I, Plachouras D, Karvanen M, Pontikis K, Jansson B, et al. Application of a loading dose of colistin methanesulfonate in critically ill patients: population pharmacokinetics, protein binding and prediction of bacterial kill. Antimicrob Agents Chemother. 2012;56:4241-9.

5. Pea F, Viale P, Pavan F, Furlanut M. Pharmacokinetic considerations for antimicrobial therapy in patients receiving renal replacement therapy. Clin Pharmacokinet. 2007:46:997-1008.

6. Honoré PM, Jacobs R, Joannes-Boyau O, Boer W, De Waele E, Van Gorp V, et al. Continuous renal replacement therapy allows higher colistin dosing without increasing toxicity. J Transl Intern Med. 2013;1:6-8.

7. Honoré PM, Jacobs R, Lochy S, De Waele E, Van Gorp V, De Regt J, et al. Acute respiratory muscle weakness and apnea in a critically ill patient induced by colistin neurotoxicity: key potential role of hemoadsorption elimination during continuous venovenous hemofiltration. Int J Nephrol Renovasc Dis. 2013;6:107-11.

\footnotetext{
* Correspondence: monica.rocco@uniroma1.it

Department of Medicine-Surgical Science and Translational medicine,

Sapienza University, Via di Grottarossa 1035, Rome 00135, Italy
} 